\title{
Salt Stress Induces Changes in Genetic Composition, Proline Content and Subcellular Organization in Potato (Solanum tuberosum L.)
}

\author{
Shaimaa S. Sobieh ${ }^{(1) \#}$, Thoria R. Mohamed ${ }^{(1)}$, Zakia M. Adam ${ }^{(1)}$, Ayman El-Fiki ${ }^{(2)}$, \\ Amal S. Awad ${ }^{(2)}$ \\ ${ }^{(1)}$ Botany Department, Faculty of Women for Arts, Science and Education, Ain Shams \\ University, Cairo, Egypt; (2) National Centre for Radiation Research and Technology, \\ Nasr City, Cairo, Egypt.
}

\begin{abstract}
GEVERAL abiotic stresses including salinity impact plant growth and reduce the productivity of many plants and field crops. Plantlets produced in vitro by tissue culture technique offer a direct and fast approach to investigate the mechanism of stress adaptation. The present study estimated the survival percentage of two potato (Solanum tuberosum L.) cultivars (Spunta and Valor) under salt stress as abiotic stresses. Some biochemical alterations and ultrastructural responses of plantlets were examined. Moreover, genetic diversity was also studied using RAPD technique. The results showed that, with the increase of external stress there was a significant decrease in the survival percentage, significant accumulation of osmoprotectants (proline) and induction of DNA damages. Furthermore, there were closing of stomatal apertures, changes in chloroplast ultrastructure and cell intercellular spaces markedly decreased. Additionally, high salt stress $(150$ and $200 \mathrm{mM} \mathrm{NaCl})$ caused complete inhibition of plantlet growth. The present work provides insight view for the adaptation of potato plantlets to salt stress through accumulating of osmoprotectants and change in molecular and ultrastructure traits.
\end{abstract}

Keywords: Potato plantlets, Saline stress, Morphological characters, DNA polymorphism, Ultrastructure changes.

\section{Introduction}

Plants are always subjected to several abiotic stresses, such as salinity, drought, chilling, freezing and several types of radiation, which could disrupt growth and development, and in severe instances may cause plant death (Krasensky \& Jonak, 2012). Cells use different strategies to avoid and /or tolerate the adverse effects of these stresses (Sairam \& Tyagi, 2004 and De Oliveira et al., 2013). Plant defence mechanisms against abiotic stresses can be either spontaneous or inducible under stress conditions (Freeman \& Beattie, 2008). Cellular responses to stress include changes in cell cycle and cell division, adjustments in the membrane system and cellular organelles, as well as alterations in gene expression profiles (Al-Safadi $\&$ Nakar, 2016). Salt stress is one of the major environmental stresses drastically affecting plant growth and productivity and it is estimated that more than one third of the world's irrigated lands is affected by salinity (Munns \& Tester, 2008). Salinity is considered the major abiotic stress to crop production, affects on different plant levels including physiology, morphology, biochemistry and molecular pathways in any plant system (Shavrukov, 2013). In the case of salt stress, the cells undergo membrane phase changing. As a result, they accumulate organic non-toxic solutes such as sugars, proline, mannitol, sorbitol and amino acids in the vacuoles of the cytoplasm, even if cells do not produce such compounds under normal conditions (De Oliveira et al., 2013). Consequently, these solutes are used to achieve the osmotic balance and to protect enzyme activity. Furthermore, plants could produce glutathione which acts as scavenger of free radicals produced by salinity (Zhu, 2007 and De Oliveira et al., 2013). As a plant system exposed to salt stress, the reactive oxygen species are produced which attack the molecular molecules including DNA resulting in genomic DNA mutations (Gill $\&$ Tuteja, 2010). There are several tools to study the effects of stresses on DNA. The most widely used is randomly amplified polymorphic DNA-polymerase chain reaction (RAPD-PCR) technique. RAPD is considered as an initial bioscreening way to identify a genetic marker resulting from PCR amplification of specific

"Corresponding author email: shimaa.sobieh@women.asu.edu.eg 
DNA segments recognized by random primers of arbitrary nucleotide sequences (Williams et al., 1990). It is the simplest and fastest of DNAbased techniques in genetic similarity studies (Gwanama et al., 2002). Yaycili \& Alıkamanoğlu (2012) used RAPD as a tool to detect the genetic variation induced by sodium chloride $(\mathrm{NaCl})$.

Moreover, electron microscopy is a standard method for imaging cellular structures with very small resolution (John \& Lonnie, 1992), very useful in localizing any damages in cells and cellular alterations of organelles under stresses (Zahra et al., 2014). The cellular organelle such as chloroplast appears to be the major target of the stress (Mitsuya et al., 2000). Changes in chloroplast ultrastructure observed under salinity were reported by Yamane et al. (2012) who found that chloroplast protrusions (CPs) are often observed under environmental stresses, similar structures surrounded by double membranes were observed in the cytoplasm and vacuole.

In this study we intended to use potato as a system to investigate the effects of salt stress manily $\mathrm{NaCl}$ at cellular and molecular levels. potato (Solanum tuberosum L.), is a critical crop in terms of food security. Its tubers are starch-rich and it is the fourth most important crop (Byun et al., 2007) after rice, wheat, and corn, with a yearly production of 300 million tons (Byun et al., 2007), but nowadays the production of it more than that. It is the most important tuberous plant, and its varieties are sensitive to many environmental stresses such as temperature, drought and salinity due to their scarce and short root systems. There is significant loss in plant growth and product yields when potato is grown under any biotic or abiotic stress (Yaycili \& Alıkamanoğlu, 2012). Several physiological and biochemical parameters are negatively affected by the presence of salt stress (Fidalgo et al., 2004). The development of efficient in vitro culture methods (tissue culture technique) has facilitated the study of any cellular and molecular changes within the cell under stress. It had been described that the in vitro selected salt-tolerant potato cell line differed genotypically from the counterpart control (Ochatt et al., 1999).

The objectives of this study are to investigate the effect of $\mathrm{NaCl}$ as stresser on different growth pramaters, the genetic variation and the biochemical changes arose within the in vitro two potato cvs. (Spunta and Valor) and study ultrastructure of chloroplasts, intercellular spaces and stomata for Valor potato $\mathrm{cv}$.

\section{Materials and Methods}

Materials

The potato tubers Solanum tuberosum L.) Spunta and Valor cultivers (these cultivars were available in healthy and uniform tubers) were obtained from Agriculture Research Centre, Giza, Egypt.

Murashige and Skoog (MS) medium supplemented with $0.2 \mathrm{mg}^{-1}$ 6-benzylamino purine (BAP), 3\% sucrose and $8 \mathrm{~g}^{-1}$ agar. the $\mathrm{pH}$ of the medium was adjusted to 5.8. Then, the following sodium chloride concentrations were added to the media $(50,75,100,150$ and 200mM).

\section{Media autocleaving}

The media were sterilized by autoclaving at $121^{\circ} \mathrm{C}$ and 20 psi for $30 \mathrm{~min}$.

\section{Eperimental design}

Buds of the two cultivars were surface sterilized by dipping in Clorox $(30 \%)$ for ten minutes followed by three rinses in sterile distilled water. Then, the buds were cultured in MS medium (Murashige \& Skoog, 1962) without hormone. Micropropagation began after 6-8 weeks when the plantlets were about $10-12 \mathrm{~cm}$ high. The culture was maintained by cutting into single nodes and transferring them onto MS medium supplemented with $0.2 \mathrm{mg}^{-1}$ 6-benzylamino purine (BAP), 3\% sucrose and $8 \mathrm{~g}^{-1}$ agar, then $\mathrm{pH}$ of the medium was adjusted to 5.8. Potatos materials were treated with the different $\mathrm{NaCl}$ concentrations and divided into two group as follows:

\section{Control (group a)}

Potato segments (seven segments in each jar/for total 15 jars) were cultured on the the previous MS medium supplemented with $0.2 \mathrm{mg}^{-1}$ 6-benzylamino purine (BAP), $3 \%$ sucrose and $8 \mathrm{~g}^{-1}$ agar.

\section{Salinity treatments (group b)}

Potato segments (seven segments in each jar/ for total 15 jars) were cultured on the MS medium supplemented with $0.2 \mathrm{mg}^{-1}$ 6-benzylamino purine (BAP), 3\% sucrose and $8 \mathrm{~g}^{-1}$ agar. Different $\mathrm{NaCl}$ concentrations $(50,75,100,150$ and $200 \mathrm{mM})$ were added. 
All The cultured jars (group a \&b) were incubated in growth chamber at $25 \pm 2^{\circ} \mathrm{C}$ under $16 \mathrm{~h} / 8 \mathrm{~h}$ photo/dark-period.

\section{Methods \\ Determination of some morphological characters}

The effect of the different treatments on bud survival percentage and some other morphological characters (such as mean of shoots, mean of nods, mean of leaves and mean of shoot length) of Spunta and Valor cvs was evaluated.

\section{Biochemical analysis:Estimation of proline content}

Proline content of control and treated potatos was determined using the method of Beatles et al. (1973). Proline content of $0.5 \mathrm{~g}$ plant materials was extracted by $3 \%$ aqueous sulfosalicylic acid. The proline extracts were reacted with $2 \mathrm{ml}$ acidninhydrin, $2 \mathrm{ml}$ of glacial acetic acid and $4 \mathrm{ml}$ toluene, then the reaction was terminated in an ice bath. The absorbancy was read at 520nm using spectrophotometer (Jasco V530). Toluene with other reactants without potato tissues were used as a blank.

\section{Molecular analysis}

DNA extraction: Genomic DNA of control group and treatment groups of Solanum tuberosum Spunta and Valor cultivars was extracted according to Doyle \& Doyle (1990). A weight of $1.5 \mathrm{~g}$ from young and fresh plantlets was grinded in liquid nitrogen and $10 \mathrm{ml}$ of preheated extraction buffer (100mM Tris- $\mathrm{HCl}, 500 \mathrm{M} \mathrm{NaCl}, 50 \mathrm{mM}$ EDTA, $1.25 \%$ SDS and $3.8 \mathrm{~g}$ sodium bisulphate). DNA samples were purified by chloroform/phenol (24:1) solution, precipetated by isopropanol, washed in $70 \%$ ethanol, then dissolved in $0.5 \mathrm{ml}$ TE buffer ( $\mathrm{pH} 8.0$ ). DNA was tested by $1.5 \%$ agarose gels electrophoresis in TE buffer at $120 \mathrm{~V}$ for $1 \mathrm{~h}$, finally DNA samples were stored at $-20^{\circ} \mathrm{C}$ for RAPD analysis.

Random amplified polymorphic DNApolymerase chain reaction ( $R A P D-P C R$ ) analysis: RAPD-PCR amplification was performed according to Williams et al. (1990) using 8 random 10 mer arbitrary primers synthesized by Operon biotechnologies, Inc. Germany. The PCR amplification was performed in a $50 \mu$ reaction volume containing $10 \mu \mathrm{l}$ My Taq Red buffer, $0.5 \mu \mathrm{l}$

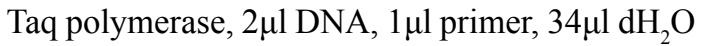
and $2.5 \mu \mathrm{LEMSO}$. Amplification was carried out in a Programmable Thermal Controller (model PTC- $100^{\mathrm{TM}}$ ). The reaction was subjected to one cycle at $94^{\circ} \mathrm{C}$ for $3 \mathrm{~min}$, followed by 34 cycles at $94^{\circ} \mathrm{C}$ for $1 \mathrm{~min}, 32.3^{\circ} \mathrm{C}$ for $30 \mathrm{sec}$, and $72^{\circ} \mathrm{C}$ for $90 \mathrm{sec}$, then a final cycle of $72^{\circ} \mathrm{C}$ for $7 \mathrm{~min}$. PCR products were run on $1.5 \%$ agarose gels to detect polymorphism between control and treated potato cvs under study. Gene ruler $^{\mathrm{TM}}$ (100bp) DNA Ladder (Fermentas \#SM0328) was used. The bands were visualized by ethidium bromide under UV transilluminator, photographed and analyzed by using Gel Doc Vilber Lourmat system. The polymorphism between control potato cvs and their treatment were estimated. The similarity between them was recorded by using NT-SYS PC 2.1 software based on Jaccard' s coefficient of similarity (Rohlf, 2000).

\section{Scanning electron microscopy (SEM)}

The leaves samples were gold sputtered for $12 \mathrm{~min}$ by using the ion sputtering device model JEOL (JFC 1100 E). The sample surface were investigated by using scanning electron microscope JEOL-5400 in National Center for Radiation Research and technology.

\section{Transmission electron microscopy (TEM)}

Leaves specimens were prepared for TEM analysis acording to John \& Lonnie (1992). About $1 \mathrm{~mm}^{2}$ of Valor leaves (control and plantlets treated with $100 \mathrm{mM}$ of $\mathrm{NaCl}$ ) were fixed in $1 \%$ potassium permanganate for $5 \mathrm{~min}$ at room temperature, then washed three times in distilled water for $15 \mathrm{~min}$ for each. Subsequently, specimens were dehydrated in graded ethanol (30\% to $90 \%)$, then in absolute ethanol followed by passage through a graded propylene oxide ethanol series finally, maintained in pure propylene oxide. Dehydrated specimens were embeded in an epoxy resin composed of, $20 \mathrm{ml}$ dodecenyl succinic anhydride (DDSA) (hardener), 16ml nadic methyl anhydride (NMA) (softener) and $8 \mathrm{ml} \mathrm{2,} \mathrm{4,} \mathrm{6-dimethylamin-ethyl-}$ phenol (DMP) (accelerator). Finally, sampels were polymerized in oven at $60^{\circ} \mathrm{C}$ for $48 \mathrm{~h}$. Sections $(1 \mu \mathrm{m})$ were cut with Leica Ultra-microtome, mounted on copper grids and stained with $0.5 \%$ uranyl acetate and lead citrate for $15 \mathrm{~min}$ (for each) according to Reynolds (1963) in Electron Microscope Unit, Center for Mycology and The Regional Biotehnology, Al Azhar University. Observations were carried out using JEOL TEM $100 \mathrm{CX}$, transmission electron microscope at $80 \mathrm{kV}$ in National Center for Radiation Research and technology. 
Statistical analysis

When it possible, the data were statistically analyzed using ANOVA analysis to determine the level of significant differences between treatments means as compared to the control at $\mathrm{P} \leq 0.05$ level of significance. The statistical software Costat (http://www.cohort.com/costat.html) was used for all analyses.

\section{$\underline{\text { Results }}$}

In this study the tissue culture technique was used to propagte the in vitro model to facilitate the study of $\mathrm{NaCl}$ effects on potato plants. The propagated treated plants were severly affected by $\mathrm{NaCl}$ as compared with their counterpart control.

Determination of some morphological characters

All the investigated morphological characters were signficantly decreased in treated Spunta and Valor cultivers after treatment with the different $\mathrm{NaCl}$ concentrations as compared with their respective control. The two concentrations 150 and $200 \mathrm{mM}$ induced a leathel effects in both cultivers causing complete death of growing plantlet (Table 1 and Fig. 1 a,b). Therfore, these two salt concentrations were excluded from the rest of the study.

\section{Biochemical analysis}

Estimation of proline content

Different $\mathrm{NaCl}$ concentrations (50, 75 and $100 \mathrm{mM}$ ) caused enhancment of proline production on both cultivers (Spunta and Valor). Proline content increased in the treated Spunta cultivar more than Valor cultivar as can be seen in Fig. 2 . The proline content was significantly increase at $\mathrm{P} \geq 0.05$ in treated Spunta reached to $64.31,76.25$ and $83.59 \mathrm{mg} / 100 \mathrm{~g}$ fresh weight, respectively by increase in salt concentrations. As well, The usage of different $\mathrm{NaCl}$ concentrations induced significant increase in the proline content in Valor $\mathrm{cv}$ reached to $70.51,73.99$ and $80.11 \mathrm{mg} / 100 \mathrm{~g}$ fresh weight, respectively as compared with their control. Moreover, there is no significant difference between the proline content in both treated cultivars.

TABLE 1. The effect of different $\mathrm{NaCl}$ concentrations on bud survival percentage and some morphological characters in Spunta and Valor potato cultivars.

\begin{tabular}{|c|c|c|c|c|c|c|c|c|c|c|c|c|}
\hline \multirow{2}{*}{$\begin{array}{l}\text { Salinity } \\
\text { concen- } \\
\text { tration }\end{array}$} & \multicolumn{2}{|c|}{$\begin{array}{l}\text { No. of growing } \\
\text { plantlets }\end{array}$} & \multicolumn{2}{|c|}{$\begin{array}{c}\text { Bud survival } \\
\text { percentage }\end{array}$} & \multicolumn{2}{|c|}{$\begin{array}{c}\text { Mean of } \\
\text { shoots }\end{array}$} & \multicolumn{2}{|c|}{ Mean of nods } & \multicolumn{2}{|c|}{$\begin{array}{c}\text { Mean of } \\
\text { leaves }\end{array}$} & \multicolumn{2}{|c|}{$\begin{array}{l}\text { Mean of shoot } \\
\text { length plantlets }\end{array}$} \\
\hline & $\begin{array}{c}\text { Spunta } \\
\text { cv. }\end{array}$ & Valor cv. & $\begin{array}{l}\text { Spunta } \\
\text { cv. }\end{array}$ & $\begin{array}{c}\text { Valor } \\
\text { cv. }\end{array}$ & $\begin{array}{c}\text { Spunta } \\
\text { cv. }\end{array}$ & $\begin{array}{c}\text { Valor } \\
\text { cv. }\end{array}$ & $\begin{array}{l}\text { Spunta } \\
\text { cv. }\end{array}$ & $\begin{array}{l}\text { Valor } \\
\text { cv. }\end{array}$ & $\begin{array}{l}\text { Spunta } \\
\text { cv. }\end{array}$ & $\begin{array}{l}\text { Valor } \\
\text { cv. }\end{array}$ & $\begin{array}{c}\text { Spunta } \\
\text { cv. }\end{array}$ & Valor cv. \\
\hline Control & $100^{\mathrm{a}} \pm 0.48$ & $101^{\mathrm{a}} \pm 0.45$ & $95.2^{\mathrm{a} \%}$ & $96.2^{\mathrm{a} \%}$ & $2^{\mathrm{a}}$ & $2^{\mathrm{a}}$ & $5^{\mathrm{a}}$ & $5^{\mathrm{a}}$ & $8^{\mathrm{a}}$ & $8^{\mathrm{a}}$ & $7.5^{\mathrm{a}} \pm 0.45$ & $8.26^{\mathrm{a} \pm} 0.49$ \\
\hline $50 \mathrm{mM}$ & $65^{b} \pm 0.35$ & $60^{b} \pm 0.75$ & $61.9^{\mathrm{bo}} \%$ & $57.1^{\mathrm{b} \%}$ & $2^{\mathrm{a}}$ & $2^{\mathrm{a}}$ & $5^{\mathrm{a}}$ & $5^{\mathrm{a}}$ & $8^{\mathrm{a}}$ & $8^{\mathrm{a}}$ & $2.0^{\mathrm{b}} \pm 0.58$ & $2.3^{b} \pm 0.22$ \\
\hline $75 \mathrm{mM}$ & $50^{\mathrm{c}} \pm 0.48$ & $41^{\mathrm{c}} \pm 0.59$ & $53.5^{\mathrm{c} \%}$ & $48.5^{\mathrm{c} \%}$ & $1^{\mathrm{b}}$ & $1^{\mathrm{b}}$ & $5^{\mathrm{a}}$ & $5^{\mathrm{a}}$ & $8^{\mathrm{a}}$ & $6^{\mathrm{b}}$ & 1. $8^{\mathrm{c}} \pm 0.07$ & $1.5^{\mathrm{c}} \pm 0.44$ \\
\hline $100 \mathrm{mM}$ & $37^{\mathrm{d}} \pm 0.63$ & $34^{\mathrm{d}} \pm 0.79$ & $35.2^{\mathrm{d} \%} \%$ & $32.4 \mathrm{~d} \%$ & $1^{\mathrm{b}}$ & $1^{\mathrm{b}}$ & $4^{b}$ & $4^{b}$ & $6^{\mathrm{b}}$ & $6^{\mathrm{b}}$ & $1.6^{\mathrm{d}} \pm 0.07$ & $1.0^{\mathrm{d}} \pm 0.10$ \\
\hline $150 \mathrm{mM}$ & 0 & 0 & 0 & 0 & 0 & 0 & 0 & 0 & 0 & 0 & 0 & 0 \\
\hline $200 \mathrm{mM}$ & 0 & 0 & 0 & 0 & 0 & 0 & 0 & 0 & 0 & 0 & 0 & 0 \\
\hline
\end{tabular}

Values (mean \pm sd) followed by different letters are significantly difference at $\mathrm{P} \leq 0.05$ level

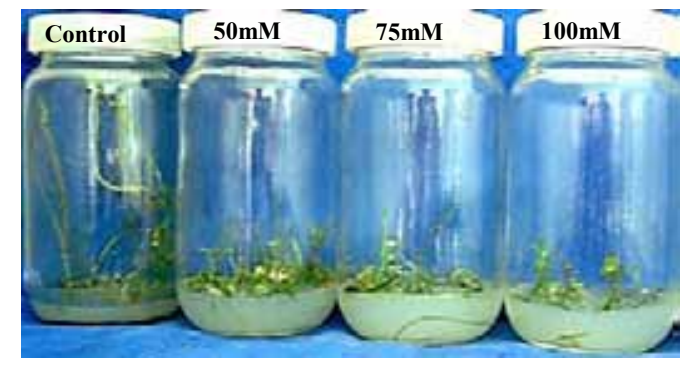

(a)

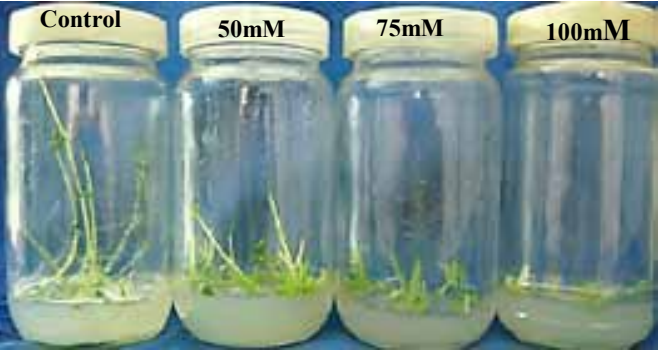

(b)

Fig. 1. The effect of different $\mathrm{NaCl}$ concentrations on bud survival percentage and some morphological characters in Spunta (a) and Valor (b) potato cultivars. 


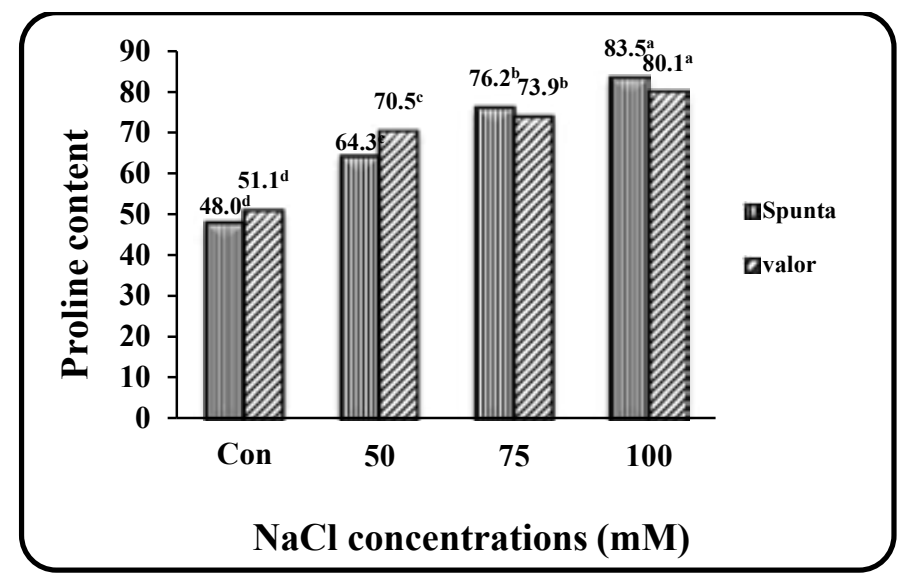

Fig. 2. Effect of different $\mathrm{NaCl}$ concentrations on proline content (mg/100g fresh weight) in Spunta and Valor cultivars [Values followed by different letters are significantly difference at $P \leq 0.05$ level].

\section{Molecular analysis}

RAPD is a genetic marker resulting from PCR amplification of DNA segments recognized by random primers of arbitrary nucleotide sequences. It is a fast and simple technique. Different levels of DNA damage may be increased due to exposure to different inducers and can be detected by changes in RAPD profiles. Table 2 and Fig. 3 illustrted the RAPD patterns of Spunta and Valor cvs treated with different $\mathrm{NaCl}$ concentrations. Spunta cv showed 52 amplified bands, 34 bands were monomorphic, 13 bands were polymorphic and 5 bands were unique bands. The polymorphism percentage was ranged from $0 \%$ to $70 \%$ with an averge of $28.62 \%$, while the average polymorphism percentage of treated Valor $\mathrm{cv}$ was $32.43 \%$. There were 48 reproducible bands amplified by the 8 used primers; 31 of them were monomorphic bands, 13 bands were polymormic and only 4 bands were unique band.

The RAPD analysis exhibited average polymorphism percentage indicates moderate level of genetic diversity between control and treated groups.

Cluster analysis represented the polymorphism in a graphic dendrogram. UPGMA analysis based on RAPD profile showed that control group is very near from the least tratment dose and very distant from the highest treatment dose (Fig. 4). In Spunta cv the treatments and control were divided into two main clusters at about 434 . The first cluster contained control Spunta only. While, the second cluster includes all treated Spunta cv with different $\mathrm{NaCl}$ concentrations 50,75 and $100 \mathrm{mM}$. The second cluster was divided into two sub clusters at about 304. In the first subcluster Spunta treated with $10 \mathrm{mM}$, which were separated from the other treatments. Valor $\mathrm{cv}$ also showed two clusters, which divided at 400 . Each cluster was divided into two subclusters. In the first sub cluster there were control valor and treated valor with $50 \mathrm{mM}$, which were similar. While treated valor with 75 and $100 \mathrm{mM}$ presented in the second subcluster and seprated at about 258 .

\section{Ultrastructure analysis of Valor $\mathrm{cv}$}

Pre-ultrastructure analysis revealed the resemblance effect of $\mathrm{NaCl}$ on both cultivars subcellular organelles, therefore we choose Valor $\mathrm{cv}$ to complete the rest of ultrastructure analysis. The ultrastructure analysis of treated Valor cultivar revealed the change in the structure of stomata and the some internal organs of the cells as compared with their control. Electron micrograph (Fig. 5 a, b) revealed that the majority of the stomata of Valor control plantlet leaf were opened and in normal shape. Figure $5 \mathrm{c}$ illustrated the ultrastructural of mesophyll cells and chloroplasts. Mesophyll cell was intact and integrated chloroplasts were still closely arranged along plasma membrane. There was large intercellular space between mesophyll cells. However, under salt treatment all stomata were closed and swollen (Fig. 5 d, e). Also, mesophyll cells showed some alterations; the intercellular spaces were reduced, as cells appeared to be linked together without space as compared with control (Fig. 5f). Chloroplasts showed irregular shape and decreased in number. The chloroplasts membrane was ruptured and there were deformation of internal structure of chloroplasts and thylakoids structure (Fig. $5 \mathrm{~g}$ ). 


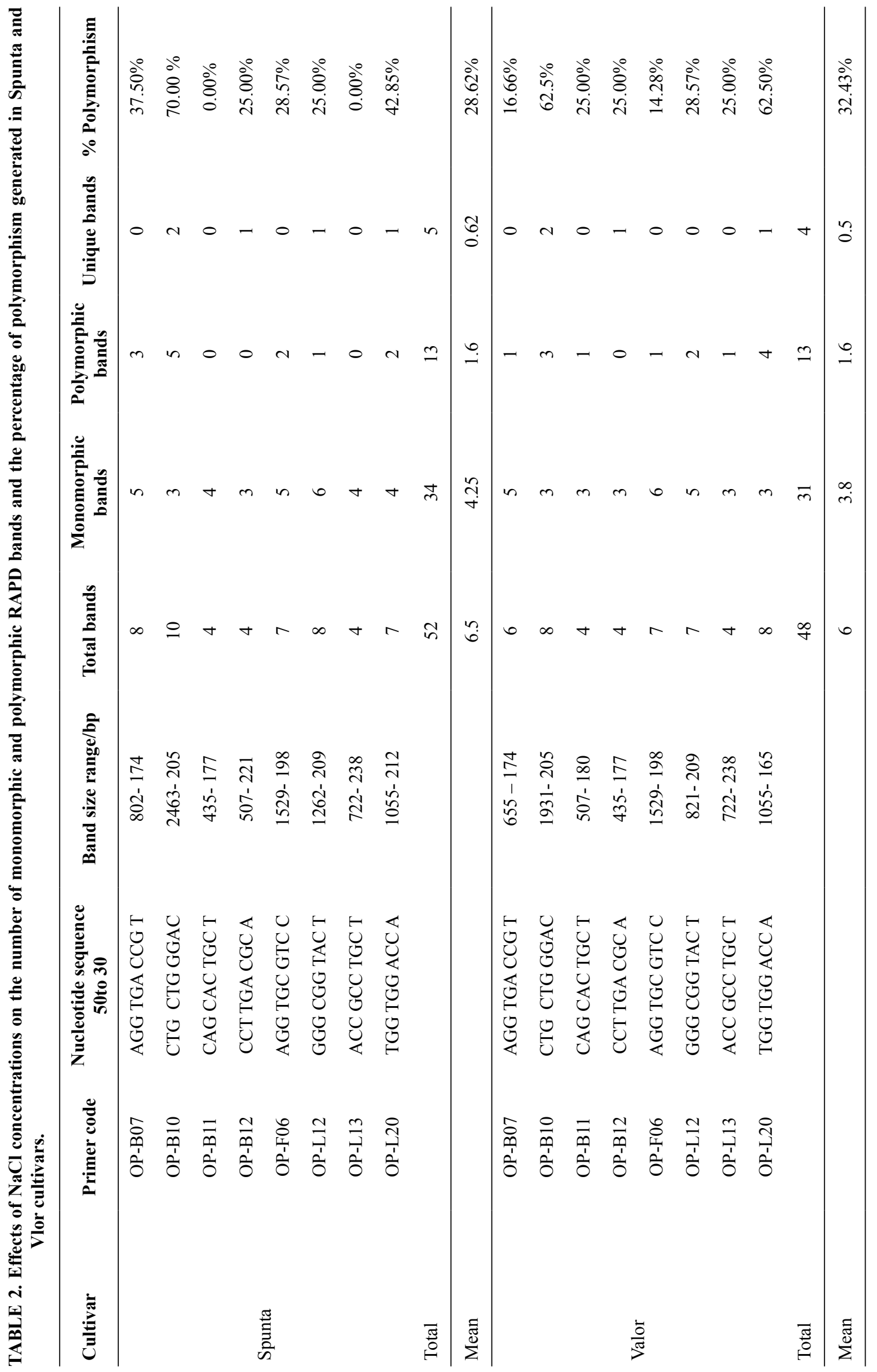

Egypt. J. Bot. 59, No.1 (2019) 

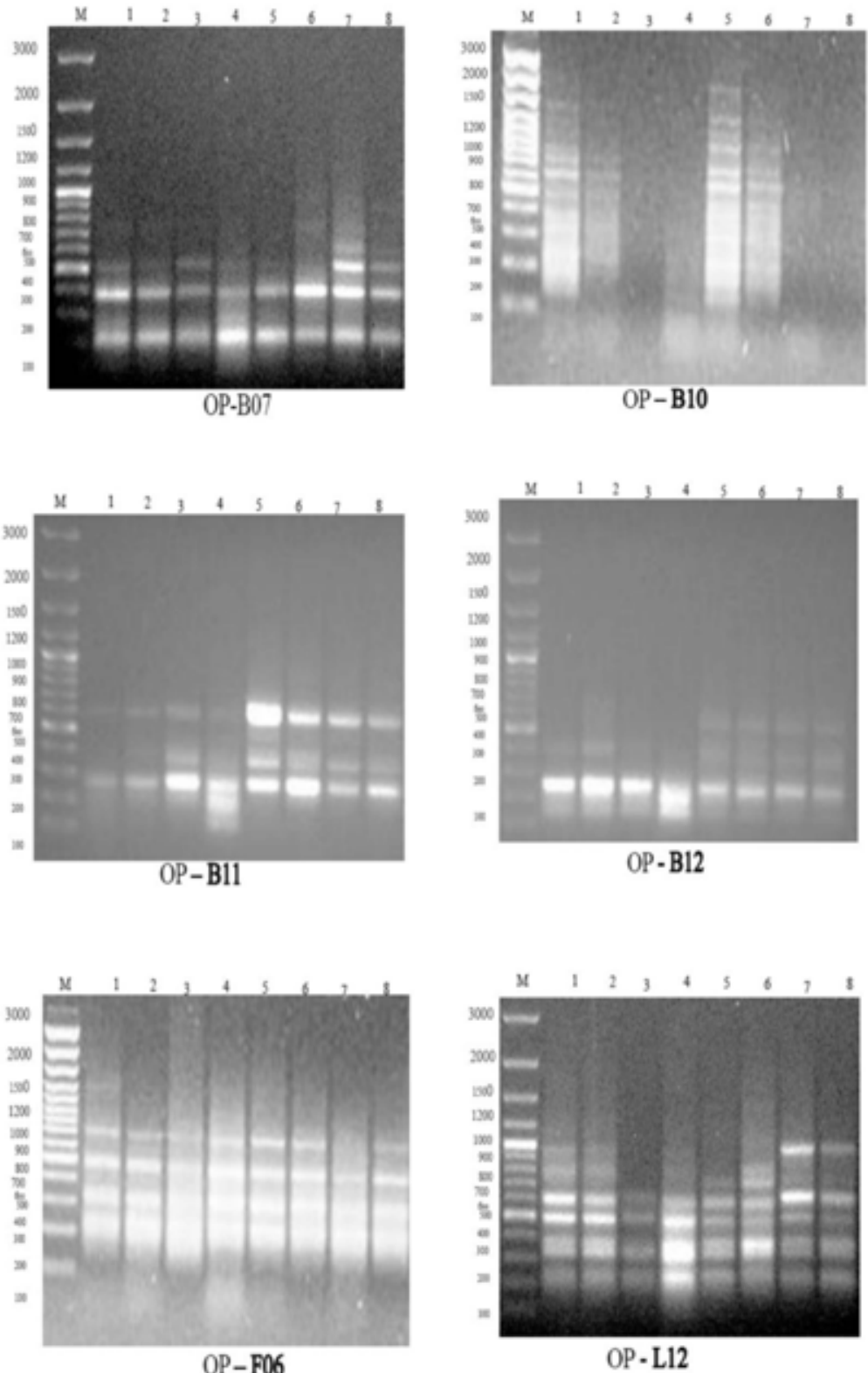

$\mathrm{OP} \cdot \mathrm{L} 12$
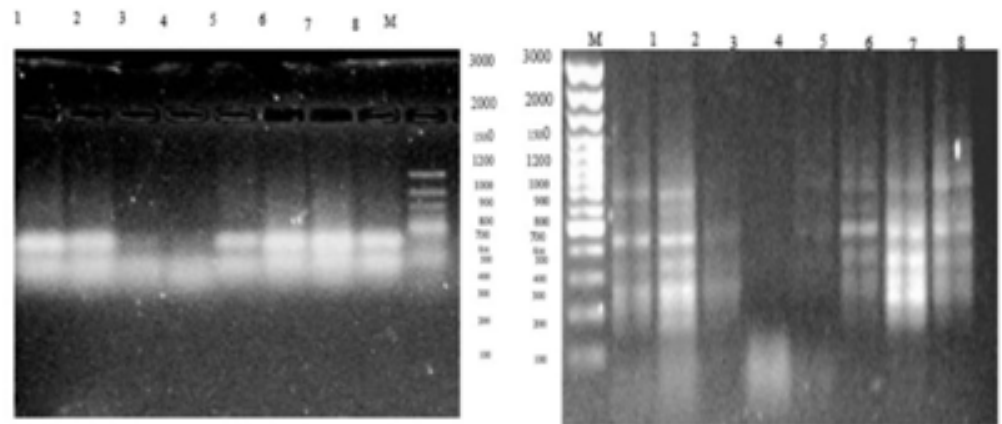

$\mathrm{OP}-\mathrm{L} 13$

$\mathrm{OP}-\mathrm{L} 20$

Fig. 3. The RAPD profiles of Valor and Spunta cultivars under salt stress.

M Marker ,1- Valor Control, 2-V 50mM, 3-V75 mM, 4- V 100mM

5- Spunta control, 6- S 50mM, 7- S 75mM, 8- S100mM. 


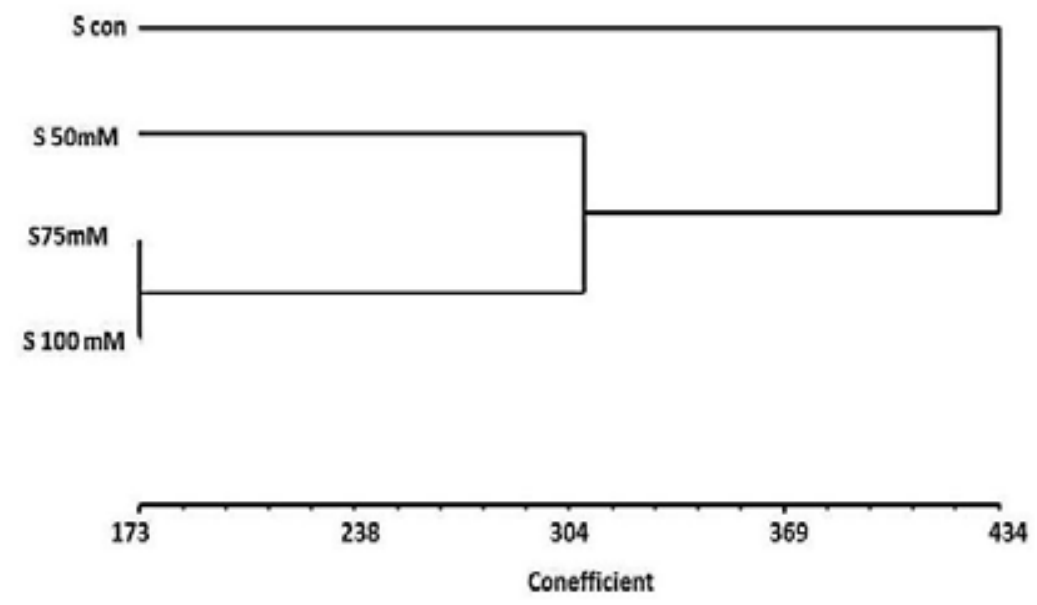

(a)

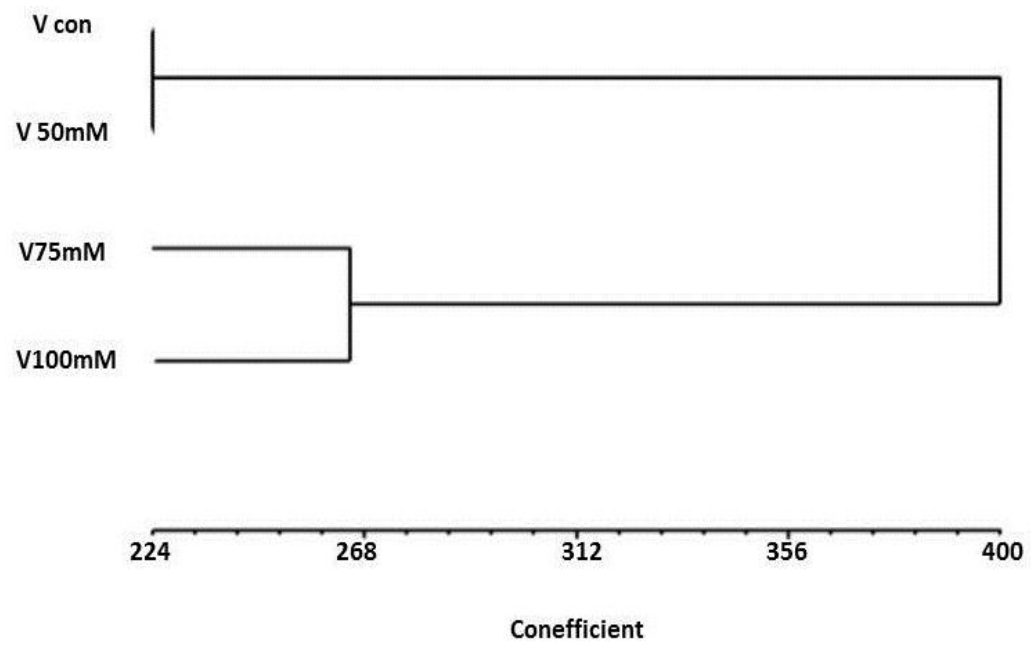

(b)

Fig. 4. Cluster analysis of potato (Solanum tuberosum $\mathrm{L}$.) plantlets growing under different $\mathrm{NaCl}$ concentrations using data from RAPD-PCR (a) Spunta cultivar and (b) Valor cultivar.

\section{Discussion}

Plant tissue culture technique provides a powerful tool to study fundamental processes in plants. One of the most important reason of tissue culture is the production of insect and virus free plants particularly for valuable vegetative plants such as potato, garlic, banana and sugar cane (Shukla et al., 2017). Abiotic stress, especially salinity stress is considered as the most serious growth limiting factor for potato crop (Vinocur \& Altman, 2005). Al-Safadi \& Nakar (2016) used tissue culture techniqe for potato tissue to investigate the way that potato plant perform to face salinity stress. Salt stress showed many adverse effects on various morphological parameters of both potato cultivers depending on the dose as reported previously by Sangle et al. (2011). The addition of $\mathrm{NaCl}$ to the culture media of potato caused depression in the osmotic potential of the media causing adverse effect on potato and other plants growth as documented by Pour et al. (2009) and Aazami et al. (2010). Khenifi et al. (2011) reported that shoot growth 
and length were significantly decreased in six potato cultivers grown in vitro with different $\mathrm{NaCl}$ concentrations. The accumulations of osmoprotectants, including proline, adapt the cell under stress by balancing the cytosolic osmotic strength with that of the external environment (Huang et al., 2013). Proline is important compatible solutes, which can be used in plant cell as scavenger of hydroxyl $(\mathrm{OH})$ radical and can interact with cellular macromolecules such as
DNA, protein and membranes where it stabilizes the structure and function of such macromolecules (Kavir et al., 2005). The high proline content has been reported during in vitro salt treated potato in many other works (Fidalgo et al., 2004 and Szabados \& Savouré, 2009). The accumulation of proline therefore could be used as an important trait in selecting tolerant species or genotypes (Ruffino et al., 2010).

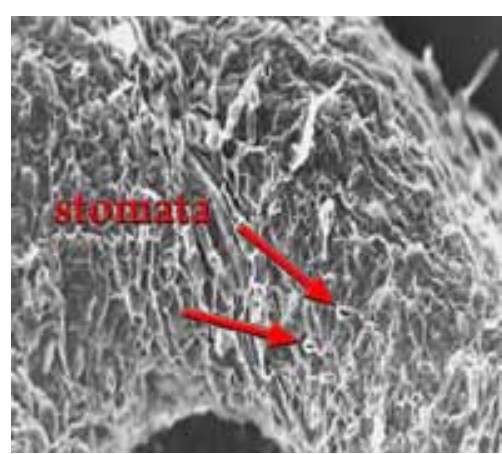

(a)

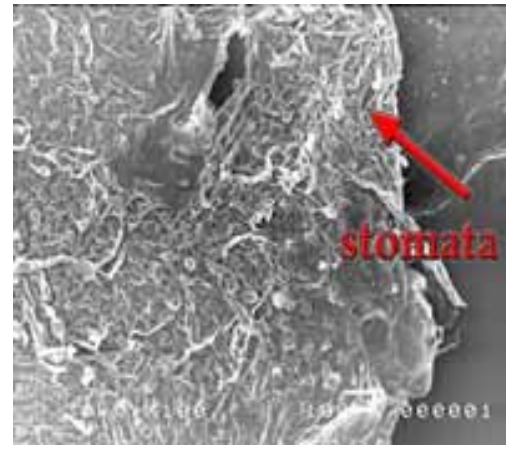

(d)

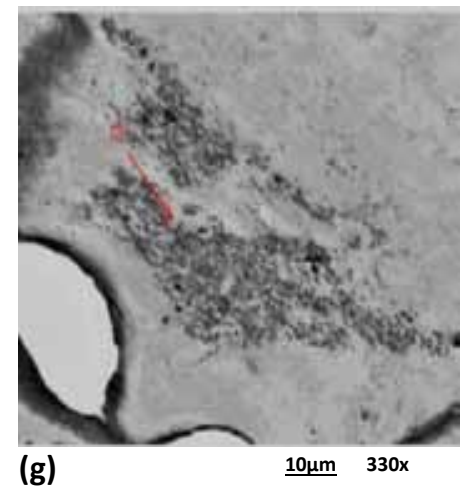

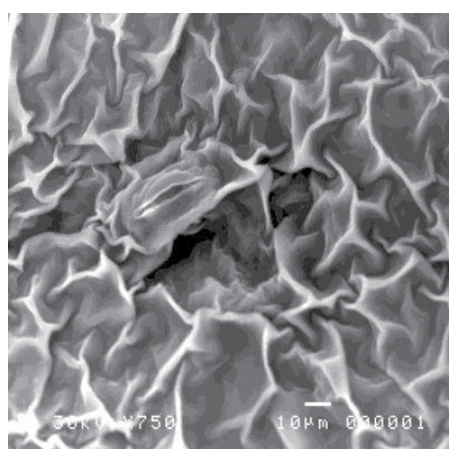

(b)

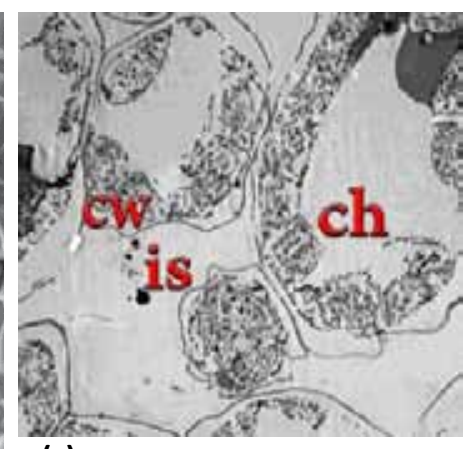

(c)

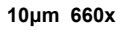

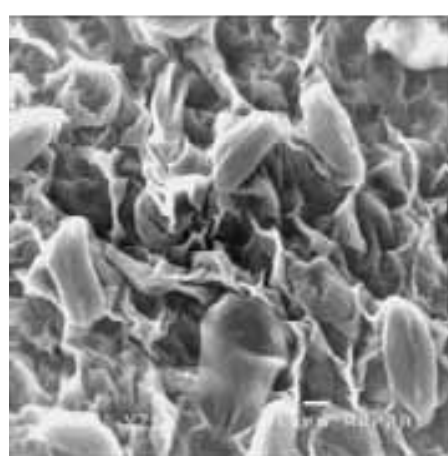

(e)

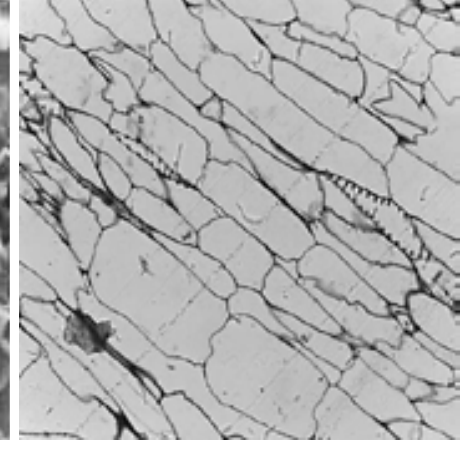

(f)

$\underline{10 \mu m}$

Fig. 5. Electron micrographs showing: (a) The normal surface structure of control Valor Leaf epidermis (SEM), (b) The normal shape opened stomata, (c) Mesophyll cells of control Valor leaf (TEM), (d) Effect of salt concentration 100mM on Valor leaf epidermis (SEM), (e) Closed stomata under salt stress (SEM), (f) Effect of salt concentration $100 \mathrm{mM}$ on mesophyll cells of Valor leaf (TEM), (g) Effect of salt concentration $100 \mathrm{mM}$ on chloroplast of Valor leaf (TEM) [ch: Chloroplasts, cw: Cell wall, is: Intercellular spaces, st: Starch grain]. 
Moreover, RAPD marker can also be used effectively to determine the variation among treated potato cultivers and control. It had been reviwed that RAPD technique is using to determine the genetic effects of $\mathrm{NaCl}$ in potato at the DNA level (Ochatt et al., 1999 and Yaycili \& Alıkamanoğlu, 2012). Likewise, salinity could induce change in gene expression pattren in the genome via histone modification, thus activating some genes and/or silencing others (Kim et al., 2012). It could also induce irregularities in the mitotic division and aberrations in the mitotic chromosomes (Barakat, 2003) thereby change the genome epigenetically (changes in the chromatin) and genetically (changes in DNA) as reported by Al-Safadi \& Nakar (2016). Afrasiab \& Iqbal (2010) stated that RAPD markers were efficient in discriminating somaclonal variants of potato. Different levels of DNA damage may be increased due to exposure to gamma rays and can be detected by changes in RAPD profiles (SenthamizhSelvi et al., 2008). The main changes in the RAPD profiles of potato cultivers under the effect of salinity were attributed to the appearance or disappearance of different bands (Ganapathi et al., 2008). Dehgahi \& Joniyasa (2017) reported that the variation in orchids by gamma radiation may correlate with the production level of DNA template after treatment which can reduce the number of binding sites for Taq polymerase. Danylchenko \& Sorochinsky (2005) reported that appearance of new bands is usually resulting from different DNA structural changes (Breaks, transpositions, deletion....etc). Afrasiab \& Iqbal (2010) informed that the presence of polymorphic bands in variants and mutants on RAPD profile showed the presence of genetic variation in all the treatments as compared to the control (Mohd et al., 2004 and Ashraf et al., 2014).

The changes in chemical contents could result in ultrastructural alteration in leaf cells. There are few reports on the effect of salinility on cell ultrastructure for tissues grown on in vitro culture (Queirós et al., 2011). The reduction of chloroplast number with swelling and distorted thylakoids, accompanied by movement of chloroplasts to the cytoplasm center are the same effect of salinity on plant cells (Shu et al., 2013). Additionally, the decrease in the intercellular spaces between cells with the increase of external salt concentration was also reported in potato cultivars by Navarro et al. (2007). Sodium ion could be used directly for osmotic adjustment under low external salt concentration (Ma et al., 2012). However, with the increase of $\mathrm{NaCl}$ concentration $>50 \mathrm{mM}$, there will be high accumulation of $\mathrm{Na}$ and $\mathrm{Cl}$ in plant leaves, leading to water loss of cell, plasmolysis and decrease of intercellular spaces in the leaves of potato plantlets as described by Kim \& Park (2010). The rupture of potato membranes after exposure to high $\mathrm{NaCl}$ concentration may be due to that salt inhibits absorption of calcium ion, leading to instability of cell membrane and cell wall. The destruction of the membrane structure caused alteration in ion homeostasis, affecting osmotic potential and inducing ion toxicity (Gao et al., 2014). The structural integrity of chloroplast is a basis of photosynthesis process for plants. Therefore, salt stress reduces photochemical efficiency and electron transport due to altered structure of thylakoids (Parida et al., 2003).

Stomata is another major structure on plant leaves that orients plant to adapt to different stress through the opening and closing of the stomatal pore (Schlüter et al., 2003). Stomata responded quickly to the environmental changes by reducing their dimensions and areas (Mehri et al., 2009). Furthermore, Imtiyaz et al. (2012) reported that changes of stomata aperture can be used for reliable survival of mutagenic progeny in in vitro and field systems. However, some studies have shown that abiotic stress treatments have no effect on stomatal number and area (Çelik et al., 2014).

\section{Conclusions}

In conclusion, the adaptation of plants to abiotic stress including salt stress is a complex process. In the present study, several parameters were studied to demonstrate cellular and molecular responses of the two potato (Solanum tuberosum L.) cultivars (Spunta and Valor). Spunta and Valor plantlets tried to face the salinity stress by accumulating proline as one of osmoprotectants, changing the molecular level by producing a moderate level of genetic polymorphism and changing organelles ultrastructure.

\section{References}

Aazami, M.A., Torabi, M. and Jalili, E. (2010) Response of some tomato cultivars to sodium chloride stress under in vitro culture condition. Afr. J. Agric. Res. 5(18), 2589-2592. 
Afrasiab, H. and Iqbal, J. (2010) In vitro techniques and mutagenesis for the genetic improvement of potato cvs desire and diamant. Pak. J. Bot. 42, 1629-1637.

Al-Safadi, B. and Nakar, X. (2016) Ultrastructural changes in potato (Solanum tuberosum) under $\mathrm{NaCl}$ mediated salinity stress in vitro. Adv. Hort. Sci. 30(2), 95-102.

Ashraf, K., Ahmad, A., Chaudhary, A., Mujeeb, M., Ahmad, S., Amir, M. and Mallick, N. (2014) Genetic diversity analysis of Zingiber Officinale Roscoe by RAPD collected from subcontinent of India. Saudi J. Biol. Sci. 21, 159-165.

Barakat, H. (2003) Interactive effects of salinity and certain vitamins on gene, expression and cell division. Int. J. Agri. Biol. 5, 219-225.

Beatles, L.S., Waldern, R.P. and Teare, I.D. (1973) Rapid determination of free proline for water stress studies. Plant and Soil, 39, 205.

Byun, M., Kwon, H. and Park, S. (2007) Recent advances in genetic engineering of potato crops for drought and saline stress tolerance. In: "Advances in Molecular Breeding Toward Drought and Salt Tolerant Crops", M.A. Jenks et al. (Eds.), pp. 713737. Springer, .

Çelik, Ö., Atak, Ç. and Suludere, Z. (2014) Response of soybean plants to gamma radiation: Biochemical analyses and expression patterns of trichome development. Plant Omics, 7, 382-391.

Danylchenko, O. and Sorochinsky, B. (2005) Use of RAPD assay for the detection of mutation changes in plant DNA induced by UV-B and Rrays. $B M C$ Plant Biol. 5(Suppl 1), S9.

De Oliveira, A.B., Alencar, N.L.M. and Gomes-Filho, E. (2013) Comparison between the water and salt stress effects on plant growth and development., In: "Responses of Organisms to Water Stress", Ș Akinci (Ed.), pp. 67-94. Open Access Publisher.

Dehgahi, R. and Joniyasa, A. (2017) Gamma irradiationinduced variation in Dendrobium sonia-28 orchid protocorm-like bodies (PLBs). Fungal Genom Biol. $7,151$.

Doyle, J.J. and Doyle, J.L. (1990) Isolation of plant DNA from fresh tissue. Focus, 12, 13-15.
Fidalgo, F., Santos, A., Santos, I. and Salema, R. (2004) Effects of long-term salt stress on antioxidant defence systems, leaf water relations and chloroplast ultrastructure of potato plants. Ann. Appl. Biol. 145, 185-192.

Freeman, B.C. and Beattie, G.A. (2008) An overview of plant defences against pathogens and herbivores. The Plant Health Instructor, APS.

Ganapathi, T.R., Meenakshi, S., Suprasanna, P., Ujjappa, K.M., Bapat, V.A. and D'Souza, S.F. (2008) Field performance and RAPD analysis of gamma-irradiated variants of banana cultivar 'Giant Cavendish' (AAA). Int. J. Fruit Sci. 8(3), 1 47-159.

Gao, H., Yang, H., Bai, J., Liang, X., Lou, Y., Zhang, J., Wang, D., Zhang, J., Niu, S. and Chen, Y. (2014) Ultrastructural and physiological responses of potato (Solanum tuberosum L.) plantlets to gradient saline stress. Front Plant Sci. 5, 787.

Gill, S.S. and Tuteja, N. (2010) Reactive oxygen species and antioxidant machinery in abiotic stress tolerance in crop plants. Plant Physiol. Biochem. 48, 909-930.

Gwanama, C., Labuschagne, M.T. and Botha, A.M. (2002) Analysis of genetic variation in Cucurbita moschata by random amplified polymorphic DNA (RAPD) markers. Euphytica, 113, 19-24.

Huang, Z., Zhao, L., Chen, D., Liang, M., Liu, Z., Shao, H. and Long, X. (2013) Salt stress encourages proline accumulation by regulating proline biosynthesis and degradation in Jerusalem artichoke plantlets. PLOS ONE, 8, e62085.

Imtiyaz, T.N., Siddique, M., Rather, Z., Nelofar, G.H. and Mir, M. (2012) Sterilization strategies for aseptic in vitro establishment and survival of shoot tip explants in Gerbera jamesonii Bolus. Appl. Biol. Res. 14, 193-197.

John, J.B. and Lonnie, D.R. (1992) "Electron Microscopy, Principles and Techniques for Biologists", $2^{\text {nd }}$ ed, Jones and Bartlett, Toronto, Canada.

Kavir, K.P.B., Sangam, S., Amrutha, R.N., Sri, L.P., Naidu, K.R., Rao, K., Rao, S., Reddy, K.J. and Sreenivasulu, N. (2005) Regulation of proline biosynthesis, degradation, uptake and transport in 
higher plants: Its implications in plant growth and abiotic stress tolerance. Cur. Sc. 88, 424-438.

Khenifi, M.L., Boudjeniba, M. and Kameli, A. (2011) Effects of salt stress on micropropagation of potato (Solanum tuberosum L.). Afr. J. Biotech. 10(40), 7840-7845.

Kim, I. and Park, S. (2010) Ultrastructural characteristics of three chenopod halophytes lacking salt excretion structures. J. Plant Biol. 53, 314-320.

Kim, J., To, T.K., Ishida, J., Matsui, A., Kimura, A.H. and Seki, M. (2012) Transition of chromatin status during the process of recovery from drought stress in Arabidopsis thaliana. Plant Cell Physiol. 53, 847-856.

Krasensky, J. and Jonak. C, (2012) Drought, salt, and temperature stress-induced metabolic rearrangements and regulatory networks. J. Exp. Bot. 63(4), 1593-1608.

Ma, Q., Yue, L.J., Zhang, J.L., Wu, G.Q., Bao, A.K. and Wang, S.M. (2012) Sodium chloride improves photosynthesis and water status in the succulent xerophyte Zygophyllum xanthoxylum. Tree Physiol. 32, 4-13.

Mehri, N., Fotovat, R., Saba, J. and Jabbari, F. (2009) Variation of stomata dimensions and densities in tolerant and susceptible wheat cultivars under drought stress. J. Food Agri. Environ. 7, 167-170.

Mitsuya, S., Takeoka, Y. and Miyake, H. (2000) Effects of sodium chloride on foliar ultrastructure of sweet potato (Ipomoea batatas Lam) plantlets grown under light and dark conditions in vitro. J. Plant Physiol. 157, 661-667.

Munns, R. and Tester, M. (2008) Mechanisms of salinity tolerance. Annu. Rev. Plant Biol. 59, 651-681.

Mohd, M.A., Ibrahim, H. and Khalid, N. (2004) Differentiation of three vaieties of Zingiber officinale Rosc. by RAPD fingerprinting. Malaysian J. Sci. 23, 135-139.

Murashige, T. and Skoog, F. (1962) A revised medium for rapid growth and bio assay with tobacco tissue cultures. Physiol. Plant, 15, 473-497.

Navarro, A., Bañon, S., Olmos, E. and Sánchez-Blanco, M.D.J. (2007) Effects of sodium chloride on water potential components, hydraulic conductivity, gas exchange and leaf ultrastructure of Arbutusunedo plants. Plant Sci. 172, 473-480.

Ochatt, S.J., Marconi, P.L., Radice, S., Arnozis, P.A. and Caso, O.H. (1999) In vitro recurrent selection of potato: Production and characterization of salt tolerant cell lines and plants. Plant Cell Tissue and Organ Cult. 55, 1-8.

Parida, A.K., Das, A.B. and Mittra, B. (2003) Effects of $\mathrm{NaCl}$ stress on the structure, pigment complex composition and photosynthetic activity of mangrove Bruguiera parviflora chloroplasts. Photosynth. 41, 91-200.

Pour, M.S., Omidi, M., Majidi, I., Davoodi, D. and Tehrani, P.A. (2009) In-vitro plantlet propagation and microtuberization of meristem culture in some of wild and commercial potato cultivars as affected by NaCl. Afr. J. Agric. Res. 5(4), 268-274.

Queirós, F., Rodrigues, J.A., Almeida, J.M., Almeida, D.P.F. and Fidalgo, F. (2011) Differential responses of the antioxidant defence system and ultrastructure in a salt-adapted potato cell line. Plant Physiol. Biochem. 49(12), 1410-1419.

Reynolds, E.S. (1963) The use of lead citrate at high $\mathrm{pH}$ as an electron-opaque stain in electron microscopy. J. Cell Biol, 17, 208-212.

Rohlf, F.J. (2000) NTSYS-pc: Numerical Taxonomy and Multivariate Analysis System Version 2.1. Exeter Publishing Setauket, New York.

Ruffino, A., Rosa, M., Hilal, M., González, J. and Prado, F. (2010) The role of cotyledon metabolism in the establishment of quinoa (Chenopodium quinoa) seedlings growing under salinity. Plant Soil, 326, 213-224.

Sairam, R.K. and Tyagi, A. (2004) Physiology and molecular biology of salinity stress tolerance in plants. Curr. Sci. 86, 407-421.

Sangle, S.M., Mahamune, S.E., Kharat, S.N. and Kothekar, V.S. (2011) Effect of mutagenesis on germination and pollen sterility in pigeon pea. Biosci Discov. 2(1), 127-130.

Schlüter, U., Muschak, M., Berger, D. and Altmann, T. (2003) Photosynthetic performance of an Arabidopsis mutant with elevated stomatal density 
(sdd1-1) under different light regimes. J. Exp. Bot. 54, 867-874.

SenthamizhSelvi, B., Ponnuswami, V. and Kavitha, P.S. (2008) Use of RAPD assay for the detection of mutation changes in aonla (Emblica officinalis Gaertn.). Adv. Nat. Appl. Sci. 2(3), 129-134.

Shavrukov, Y. (2013) Salt stress or salt shock: Which genes are we studying? J. Exp. Bot. 64,119-127.

Shu, S., Yuan, L.Y., Guo, S.R., Sun, J. and Yuan, Y.H. (2013) Effects of exogenous spermine on chlorophyll fluorescence, antioxidant system and ultrastructure of chloroplasts in Cucumis sativus L. under salt stress. Plant Physiol. Biochem. 63, 209-216.

Shukla, M.R., Singh, A.S., Piunno, P.K. and Jones, A.M.P. (2017) Application of 3D printing to prototype and develop novel plant tissue culture systems. Plant Meth. 13(6), 1-10.

Szabados, L. and Savouré, A. (2009) Proline: A multifunctional amino acid. Trends Plant Sci. 15, 89-97.

Vinocur, B. and Altman, A. (2005) Recent advances in engineering plant tolerance to abiotic stress achievements and limitations. Curr. Opin. Biotech. 166, 123-132.
Williams, J.G.K., Kubelkn, A.R., Livak, K.J., Rafalski, J.A. and Tingey, V.A. (1990) DNA polymorphisms amplified by arbitrary primers are useful as genetic markers. Nucl. Acid Res. 18(22), 6231-6235.

Yamane, K., Mitsuya, S., Taniguchi, W. and Miyake, H. (2012) Salt-induced chloroplast protrusionis the process of exclusion of ribulose-1,5-bisphosphate arboxylase/oxygenase from chloroplasts into cytoplasm in leaves of rice. Plant Cell Environ. 35, 1663-1671.

Yaycili, O. and Alıkamanoğlu, S. (2012) Induction of salt-tolerant potato (Solanum tuberosum L.) mutants with gamma irradiation and characterization of genetic variations via RAPD-PCR analysis. Turk. J. Biol. 36, 405-412.

Zahra, J., Nazim, H., Cai, S., Han, Y., Wu, D., Zhang, B., Imran, S. and Zhang, G. (2014) The influence of salinity on cell ultrastructures and photosynthetic apparatus of barley genotypes differing in salt stress tolerance. Acta Physiol. Plant, 36, 1261-1269.

Zhu, J.K. (2007) Plant salt stress. Encyclopedia of life sciences, John Wiley \& Sons, Ltd, UK.

Received 10/4/2018; accepted 24/12/2018) 


\section{التغيرات في التركيب الجيني، محتوى البرولين والتنظيم التحت خلوي في نبات البطاطس تحت الإجهاد الملحي في التركي \\ شيماء سلمي صبيح(1)، ثريا رشاد محمد(1)، زكية محمد ادم (1)، ، ايمن الفقي(2)، أمل صلاح علي عواد(2)

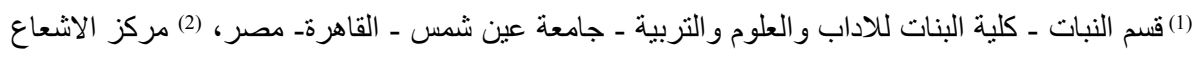 و التكنولوجيا ـ هيئة الطاقة الذرية ـ القاهرة ـ مصر.}

تؤثر العديد من الضغوط اللاإحيائية على نمو النباتات وتقلل إنتاجية العديد من النباتات و المحاصيل الحقلية. نوفر

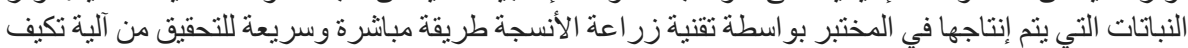
النبات مع الإجهاد الخارجى الو اقع عليه.

وقد قامت الدر اسة الحالية بتقدير نسبة الحيوية لصنفى البطاطس سبونتا وفالور الناتجين من تقنية زر اعة اعنة

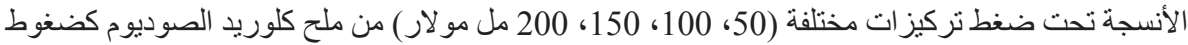
غير حيوية.

تم تقدير بعض التغير ات البيوكيميائية والاستجابات التركيبية داخل خلايا البطاطس من الصنفين، علاوة على بلى

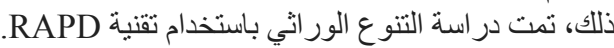

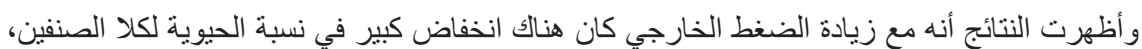

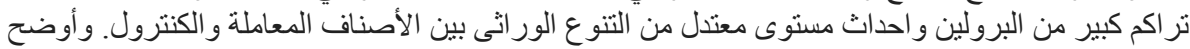

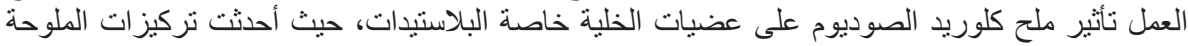

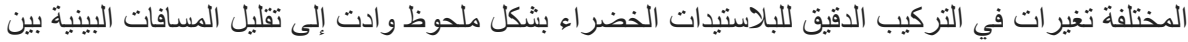

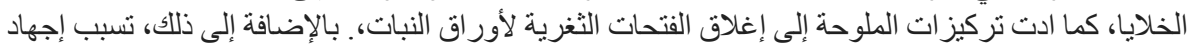

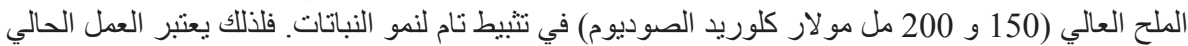

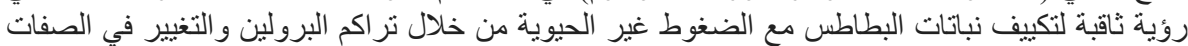
الجزيئية والتركيبية. 